Perceptual \& Motor Skills: Physical Development \& Measurement 2012, 115, 2, 521-533. (C) Perceptual \& Motor Skills 2012

\title{
ASSOCIATIONS OF PHYSICAL ACTIVITY WITH DRIVING-RELATED COGNITIVE ABILITIES IN OLDER DRIVERS: AN EXPLORATORY STUDY ${ }^{1,2}$
}

\section{JOSÉ MARMELEIRA}

Department of Sport and Health

University of Évora

Research Center in Sports Sciences Health Sciences, and Human Development

(CIDESD) Portugal
INÊS FERREIRA

Centro de Investigacão do Núcleo de Estudos e Intervenção Cognitivo Comportamental (CINEICC)

Faculty of Psychology and Educational Sciences University of Coimbra, Portugal

\section{FILIPE MELO AND MÁRIO GODINHO}

\author{
Biolad Group of the Interdisciplinary Centre for the Study of Human Performance (CIPER), \\ Laboratory of Motor Behavior, Faculty of Human Kinetics \\ Technical University of Lisbon, Portugal
}

Summary. - The purpose of this study was to examine the associations between physical activity and driving-related cognitive abilities of older drivers. Thirtyeight female and male drivers ages 61 to 81 years $(M=70.2, S D=5.0)$ responded to the International Physical Activity Questionnaire and were assessed on a battery of neuropsychological tests, which included measures of visual attention, executive functioning, mental status, visuospatial ability, and memory. A higher amount of reported physical activity was significantly correlated with better scores on tests of visual processing speed and divided visual attention. Higher amounts of physical activity was significantly associated with a better composite score for visual attention, but its correlation with the composite score for executive functioning was not significant. These findings support the hypothesis that physical activity is associated with preservation of specific driving-related cognitive abilities of older adults.

Aging is associated with a decline in several cognitive abilities and brain functions (Brennan, Welsh, \& Fisher 1997; Spirduso, Francis, \& MacRae 2005; Bixby, Spalding, Haufler, Deeny, Mahlow, Zimmerman, et al. 2007), which can result in driving difficulties (Lundberg, HakamiesBlomqvist, Almkvist, \& Johansson 1998; Daigneault, Joly, \& Frigon 2002). Older drivers have a high crash rate per distance travelled (Preusser, Williams, Ferguson, Ulmer, \& Weinstein 1998; Guerrier, Manivannan, \& Nair 1999; Lyman, Ferguson, Braver, \& Williams 2002) and an increased risk of injury or death in a traffic crash (McGwin, Sims, Pulley, \& Roseman 2000; Li, Braver, \& Chen 2003).

Older adults with higher levels of physical activity and physical fitness

${ }^{1}$ Address correspondence to José Marmeleira, Pavilhão Gimnodesportivo da Universidade de Évora, Prolongamento da Rua de Reguengos de Monsaraz, 14, 7000-727 Évora, Portugal or e-mail (jmarmel@uevora.pt).

${ }^{2}$ Part of this research was supported by a scholarship from the Portuguese Foundation for Science \& Technology committee to the first two authors. 